\title{
Pidana Mati Ditinjau Dari Prespektif Sosiologis dan Penegakan HAM
}

\author{
Auliah Andika Rukman \\ Universitas Muhammadiyah Makassar \\ auliah.andika113@gmail.com
}

\begin{abstract}
ABSTRAK
Pidana mati merupakan salah satu jenis pidana yang paling kontroversial di dunia, banyak pendapat yang mendukung dan juga menentang penerapan hukuman ini pihak yang mendukung pidana mati umumnya didasarkan pada alasan konvensional yaitu pidana mati sangat dibutuhkan guna menghilangkan orang-orang yang dianggap membahayakan kepentingan umum atau negara, dan dirasa tidak dapat diperbaiki lagi, sedangkan mereka yang menentang penerapan pidana mati ini lazimnya menjadikan alasan bahwa hukuman mati ini bertentangan dengan hak asasi manusia dan merupakan bentuk pidana yang tidak dapat lagi diperbaiki apabila setelah eksekusi dilakukan kemudian ditemukan kesalahan atas vonis yang dijatuhkan oleh hakim.
\end{abstract}

Kata Kunci : Pidana, Mati, Penegakan HAM

\section{PENDAHULUAN}

Pidana mati merupakan salah satu jenis pidana yang tertua dalam usianya, setua usia kehidupan manusia dan paling kontroversial dari semua sistem pidana, baik di negara-negara anglosaxon dengan aliran hukumnya common law system, maupun di negara-negara Eropa kontinental yang sistem hukumnya civil law. Penelusuran historis terhadap hukuman mati, telah berhasil membuktikan bahwa dewasa ini, di negara-negara diberbagai belahan dunia selalu saja mempermasalahkan penerapan hukuman mati itu.

Di Indonesia Pidana mati mulai berlaku pada tanggal 1 Januari 1918 sebagaimana tercantum dalam Wetboek Van strafrecht (KUHP) yang ditetapkan oleh pemerintah kolonial Belanda berdasarkan K.B.v. 15 Oktober 1915, No. 33. S. 15-732 jis. 17-497, 645 yakni W.v.S yang sudah berlaku di Hindia Belanda. Peninjauan pidana mati telah dinasionalisasikan dengan UU Nomor 1 Tahun 1946 yang delik-deliknya itu terdapat dalam pasal 10 KUHP dan ada pula delik yang tersebar diluar KUHP dalam wujud UU. Ketentuan itu telah ditransformasikan dalam memori penjelasan (Memorie van Toelichting), bahwa negara berhak untuk menjalankan semua peraturan ini, termasuk pidana mati sebagai keharusan dengan maksud agar negara dapat memenuhi kewajibannya untuk menjaga ketertiban hukum dan kepentingan umum (A. Hamzah dan A, Sumangelipu, 1984). 
Pelaksanaan pidana mati di beberapa negara di dunia sebenarnya telah mengalami pro dan kontra, yaitu sejak sejak dipublikasikannya buku "Dei Dellitti E Delle Pene" oleh Cesare Beccaria (1764), dan pengaruh tulisannya itu terasa kembali berkibar dan berpengaruh besar antara masa perang dunia I dan II yang mendorong bangkitnya aliran humanisme. Intinya, pengakuan eksistensi kemartabatan manusia akan tuntutan penghargaan hak asasi manusia, terutama hak atas hidup (rights to life) dan hak-hak sosial lainnya. Kaum retensionis (pro) merumuskan pidana mati lazimnya itu bersifat transcendental, dibangun dari conceptual abstraction, yang mencoba melihat pidana mati hanya dari segi teori absolut, dengan aspek pembalasannya dan unsur membinasakan. Dalam pengertian khusus teori absolut, bahwa pidana mati bukanlah pembalasan melainkan refleksi dan manifestasi sikap muak masyarakat terhadap penjahat dan kejahatan, maka nestapa yuridis berupa hukuman mati harus didayagunakan demi menjaga keseimbangan dalam tertib hukum. Sedangkan kaum Abolisionis (kontra) menyuarakan bahwa negara tidak mempunyai hak mencabut nyawa orang. Sejak munculnya gerakan abolisionis ini berdampak kepada banyak negara yang mengurangi jenis-jenis tindak pidana yang diancam dengan hukuman mati (Todung Mulya Lubis, 2009 : 225).

Pro dan Kontra penerapan hukuman mati di Indonesia saat ini mulai bermunculan, apalagi pemberitaan mengenai eksekusi mati kepada penjahat Narkoba sedang marakmaraknya sebagian orang menyetujui tentang hukuman mati ini tapi di lain pihak ada juga yang tidak menyetujuinya. Berbagai sudut pandang digunakan untuk memperkuat argumen mereka tentang sah atau tidaknya hukuman mati ini, mulai dari sisi agama, hak asasi manusia, hukum, sosial budaya sampai pada paham yang dianut suatu Negara.

\section{PEMBAHASAN}

\section{Aspek Sosiologis Penerapan Pidana Mati di Indonesia}

Dalam prespektif sosiologis, hukuman mempunyai arti sosial yang tertentu oleh karena kekuatan suatu sanksi tergantung pada persepsi manusia mengenai sanksi/hukuman tersebut. Durkheim, mengkaitkan jenis sanksi dengan jenis solidaritas sosial masyarakat. Pada solidaritas mekanis yang didasarkan pada kesamaan dan loyalitas yang total dari individu, maka sanksi yang diterapkan bersifat represif. Penjatuhan sanksi bertujuan untuk menghukum kejahatan atau menghukum perbuatan yang melanggar ketentuan sosial yang dianut. Sehingga sanksi/hukuman dapat dianggap sebagai alat untuk memuaskan kesadaran bersama. Pada masyarakat dengan solidaritas organis yang 
didasarkan pada deferensiasi antara individu, maka sanksi/hukumannya bersifat restitutif. Oleh karena itu, yang diperlukan adalah hukuman yang bersifat akomodatif, sifatnya adalah menjaga perbedaan-perbedaan itu agar tidak menjadi disintegratif. Selain dari persepsi orang terhadap sanksi, manusia juga mempunyai taraf toleransi yang berbedabeda terhadap penderitaan sebagai akibat pelanggaran. Kedudukan sosio - ekonomi juga berpengaruh pada penjatuhan hukuman mati bagi seseorang. Seperti yang diungkapkan dalam kajian di Amerika, disebutkan bahwa hukuman mati akan mempunyai pengaruh yang sangat besar terhadap warga masyarakat yang miskin dan minoritas, apabila dibandingkan dengan mereka yang berasal dari golongan kulit putih. Hal ini terkait dengan bantuan hukum bagi terdakwa. Mereka juga lebih banyak dihukum mati jika dibantu oleh pengacara yang diitunjuk pengadilan dibandingkan dengan jika didampingi oleh pengacara pribadi (Satjipto Rahardjo 2009 : 27).

Faktor terpenting dari hukuman mati adalah faktor kematian itu sendiri. Dari aspek medis, kematian diindikasikan dengan kematian fisik, namun kematian yang mungkin terjadi sesungguhnya tidak hanya kematian fisik, tetapi juga kematian sosial. Dari sudut pandang sosiologis, seseorang bisa disebut masih hidup secara fisik, tetapi sekaligus mengalami kematian sosial. Hal tersebut terjadi di saat seseorang berada dalam kondisi sosial sedemikian rupa, sehingga kebebasannya untuk melakukan aktifitas social dirampas habis. Kematian sosial bisa menjadi suatu alternatif penting dalam bentuk sanksi pidana untuk menggantikan pidana mati. Dapat dibayangkan bagaimana seseorang yang dijatuhi hukuman dua kali seumur hidup tanpa kemungkinan keringanan, secara fisik ia hidup tetapi mungkin penderitaan yang dialaminya adalah lebih berat dan panjang, terutama dari segi penderitaan sosial. Terpidana ini terisolasi dari rutinitas kehidupan sosialnya dan hal ini merupakan pukulan yang sangat berat, terlebih harus dipisahkan dari keluarga dekatnya selama ini (Satjipto Rahardjo 2009 : 28).

Menurut Satjipto Rahardjo (2009 : 29),dalam hukum sesungguhnya telah dikenal istilah "kematian perdata". Konon kematian seperti ini pernah menimpa sejumlah orang pada masa pemerintahan orde baru lalu. Karena dianggap membahayakan penguasa, maka tanpa melalui proses peradilan, mereka dimatikan secara perdata. Orang yang terkena kematian perdata itu masih hidup segar bugar, tetapi jaringan kehidupan sosialnya banyak dimatikan, misalnya ia tidak dapat lagi melakukan usaha bisnisnya seperti biasa dan demikian juga dengan pembatasan terhadap berbagai aktifitas sosialnya. Pidana kematian sosial ini pada dasarnya dapat memberikan efek jera yang luar biasa sekaligus menjadi suatu evaluasi tepat terhadap suatu vonis hukuman, apakah vonis hukuman yang 
dijatuhkan pengadilan itu memang benar atau justru keliru dan berbanding terbalik dengan fakta kebenaran yang ada. Bagi orang yang telah dijatuhi pidana mati dan eksekusi sudah dilaksanakan, maka tidak ada sesuatu apapun yang dapat diperbaiki.

Apabila ternyata dibelakang hari terjadi kekeliruan terpidana tetap akan mati, sekalipun ternyata bukan dia yang melakukan perbuatan yang didakwakan. Ia tidak dapat lagi dihidupkan, meskipun nama baiknya dapat dipulihkan. Pada solidaritas mekanis yang didasarkan pada kesamaan dan loyalitas yang total dari individu, maka sanksi yang diterapkan bersifat represif. Penjatuhan sanksi bertujuan untuk menghukum kejahatan atau menghukum perbuatan yang melanggar ketentuan sosial yang dianut. Sehingga sanksi/hukuman dapat dianggap sebagai alat untuk memuaskan kesadaran bersama.

Kecenderungan para ahli yang setuju pidana mati tetap dipertahankan eksistensinya, umumnya didasarkan pada alasan konvensional yaitu pidana mati sangat dibutuhkan guna menghilangkan orang-orang yang dianggap membahayakan kepentingan umum atau negara dan dirasa tidak dapat diperbaiki lagi, sedangkan mereka yang kontra terhadap pidana mati lazimnya menjadikan alasan pidana mati bertentangan dengan hak asasi manusia dan merupakan bentuk pidana yang tidak dapat lagi diperbaiki apabila setelah eksekusi dilakukan diemukan kesalahan atas vonis yang dijatuhkan hakim (A. Hamzah dan A, Sumangelipu, 1984: 25). Menurut The Indonesian Human Rights Watch dalam ( Waluyadi, 2009 : 58) terdapat tiga alasan utama mengapa penjatuhan hukuman mati seringkali digunakan oleh pengadilan, antara lain:

1. Hasil penerapan ancaman pidana mati digunakan oleh rezim kolonial Belanda, kemudian dalam prakteknya terus digunakan sampai rezim otoritarian Orde Baru untuk memberikan rasa takut bahkan menghabiskan lawan politik. Hal ini dapat dilihat pada penerapan kejahatan politik Pasal 104 KUHP;

2. Upaya menerbitkan beberapa ketentuan hukum baru yang mencantumkan ancaman pidana mati sebagai langkah konpensasi politik akibat ketidakmampuan membenahi sistem hukum yang korup. Padahal ancaman pidana mati tidak pernah bisa membuktikan efektifitasnya mengurangi angka kejahatan termasuk narkoba

3. Meningkatnya angka kejahatan dilihat semata sebagai tanggung jawab individu pelaku.

Pro dan Kontra penerapan pidana mati di Indonesia tidak hanya terjadi di tingkat kalangan ahli hukum saja, perdebatan seputar pidana mati ini pun timbul hingga ke level masyarakat dan berlanjut sampai ke tahap Mahkamah Konstitusi, beberapa terpidana mati kasus Narkoba misalnya melalui kuasa hukumnya mengajukan Permohonan Pengujian 
materil Undang-Undang Nomor 22 tahun 1997 Tentang Narkotika terhadap UndangUndang Dasar 1945 yang berkenaan dengan inkonstitusionalitas pidana mati sebagaimana termaktub di dalam Undang-Undang Nomor 22 tahun 1997 Tentang Narkotika. Namun Berdasarkan Putusan Mahkamah Konstitusi tersebut, secara tegas dinyatakan bahwa ancaman pidana mati pada Undang-Undang Nomor 22 tahun 1997 Tentang Narkotika tidaklah bertentangan dengan Konstitusi. Secara analogi dapat ditarik sebuah kesimpulan bahwa pidana mati bukanlah suatu tindakan inkonstituional (Nata Sukam Bangun, 2014 : $8)$.

Beberapa kalangan masyarakat yang pro terhadap pidana mati ini beranggapan bahwa untuk kejahatan seperti Narkoba yang dikategorikan sebagai kejahatan Extraordinary Crime (kejahatan Luar biasa) sudah sepantasnya apabila pelakunya dikenai sanksi pidana yang berat hingga pemberian pidana mati mengingat kejahatan jenis ini mampu merusak seluruh lapisan generasi bangsa. Hal ini sebagaimana yang dikemukakan oleh Hartawi AM dalam (Djoko Prakoso dan Nurwachid, 1985: 14) yang memandang bahawa ancaman dan pelaksanaan pidana mati sebagai suatu social defence. Pidana mati adalah suatu pertahanan sosial untuk menghindarkan masyarakat umum dari bencana dan bahaya ataupun ancaman kejahatan besar yang mungkin terjadi yang akan menimpa masyarakat, yang telah atau akan mengakibatkan kesengsaraan dan mengganggui ketertiban serta keamanan rakyat umum, dalam pergaulan manusia bermasyarakat dan bergama. Adanya bahaya-bahaya dan kejahatan-kejahatan besar yang menimpa dan mengancam kehidupan masyarakat, memberikan hak pada masyarakat sebagai kesatuan untuk menghindarkan dan pembelaan terhadap kejahatan dengan memakai senjata, salah satunya adalah pidana mati. Bila pidana mati mendapat dukungan dari berbagai kalangan yang ingin tetap mempertahankannya, maka ia juga mendapat penentang yang semakin hari semakin banyak jumlahnya.

Lain lagi halnya apabila penerapan pidana mati ini ditinjau dari tujuan pemidananaan, menurut J.E. Sahetapy $(1978,29)$ tujuan pidana bukanlah untuk membalas perbuatan jahat dari si pelaku. Sebab bagaimanapun perbuatannya itu sudah terjadi dan tidak perlu lagi disesali; korban telah jatuh. Pernyataan ini, ditunjang dengan asumsi bahwa si pelaku menganggap pidana bagianya bukan suatu penderitaan, karena bagimanapun juga si pelaku merasa puas dan senang bahwa lawannya (si korban) telah memperoleh suatu imbalan penderitaan. Ini berarti, bahwa kejahatan sebagai tingkah laku bersifat simptomatik, tidak hanya si pelaku, melainkan juga dalam hubungan antara si pelaku dan si korban, oleh karena seringkali si korban juga memiliki sifat-sifat yang 
menimbulkan kecenderungan untuk dijadikan mangsa dan dengan demikian ikut bertanggung jawab juga. Oleh karena itu, pembalasan dalam bentuk apapun tidak akan membawa suatu keseimbangan kembali, kecuali memuaskan nafsu bahwa sipelaku telah memperoleh imbalan penderitaan

\section{Pidana Mati ditinjau dari Proses Penegakan HAM di Indonesia}

Di Indonesia yang berlaku KUHP buatan pemerintah Belanda sejak 1 Januari 1918, dalam pasal 10 masih mencantumkan pidana mati dalam pidana pokoknya, padahal di Belanda sendiri pidana mati sudah dihapuskan Pada tahun 1870. Hal tersebut tak diikuti di Indonesia karena keadaan khusus di Indonesia menuntut supaya penjahat yang terbesar dapat dilawan dengan pidana mati (Andi Hamzah dan A. Sumangelipu, 1984 : 15 ) Dengan berkiblat pada sistem hukum Belanda, Indonesia kemudian melenggang dengan pidana mati sebagai andalan untuk menuntaskan berbagai kejahatan seperti pembunuhan. Sayangnya, perjalanan hukum Indonesia tak semulus seperti yang disangka. Sebab, beberapa hal yang menimbulkan polemik sempat mewarnai posisi pidana mati di Indonesia. Salah satunya adalah gerakan anti hukuman mati yang sempat panas tahun 1958 di bawah komando Prof. Mr. Roeslan Saleh, sang pelopor gerakan penghapusan pidana mati (abolisionis) di Indonesia. Ditambah dengan kiprah Wakil Presiden Republik Indonesia Adam Malik yang tahun 1978 juga memimpin gerakan tersebut (Andi Hamzah dan A. Sumangelipu, $1984: 15$ ).

Dari perspektif Internasional ketentuan mengenai Hak Asasi Manusia yang berkaitan dengan Hak Hidup dapat ditemukan dalam International Covenant on Civil and Political Right (ICCPR) yang mengatur hak untuk hidup. Pasal 6 ayat 1 ICCPR berbunyi setiap Manusia berhak atas hak untuk hidup dan mendapat hak perlindungan hukum dan tiada yang dapat mencabut hak itu. Selanjutnya Pasal 6 ayat 2 menyatakan bagi Negara yang belum menghapus ketentuan Pidana Mati, putusan tersebut hanya berlaku pada kejahatan yang termasuk kategori yang serius sesuai hukum yang berlaku saat itu dan tak bertentangan dengan covenant ini dan Convention on Prevention and Punishment of Crime Of Ghenoside pidana tersebut hanya dapat melaksanakan merujuk pada putusan final yang diputuskan oleh Pengadilan yang Kompeten (Todung Mulya Lubis : 2007)

Kalangan internasional telah banyak melakukan tindakan untuk penghapusan hukuman mati di dunia. Salah satunya yaitu Deklarasi Universal Hak Asasi Manusia (DUHAM) yang secara tegas menyatakan bahwa hukuman mati telah melanggar dua ketentuan hak dasar manusia. Yaitu, tidak ada satupun yang berhak mencabut hak hidup setiap orang dan tidak ada satu orang pun yang berhak melakukan hukuman yang dapat 
merendahkan martabat dan menimbulkan penyiksaan (Todung Mulya Lubis : 2007). Lebih lanjut, dalam Penjelasan Pasal 9 UU HAM dikatakan bahwa setiap orang berhak atas kehidupan, mempertahankan kehidupan, dan meningkatkan taraf kehidupannya. Hak atas kehidupan ini bahkan juga melekat pada bayi yang belum lahir atau orang yang terpidana mati. Dalam hal atau keadaan yang sangat luar biasa yaitu demi kepentingan hidup ibunya dalam kasus aborsi atau berdasarkan putusan pengadilan dalam kasus pidana mati. Maka tindakan aborsi atau pidana mati dalam hal dan atau kondisi tersebut, masih dapat diizinkan. Hanya pada dua hal tersebut itulah hak untuk hidup dapat dibatasi. Dari penjelasan Pasal 9 UU HAM di atas dapat diketahui bahwa dalam kondisi tertentu seperti pidana mati, hak untuk hidup dapat dibatasi.

Perdebatan pidana mati kembali lagi mencuat terkait dengan uji materi pasalpasal dalam undang-undang tentang Narkotika, pada bulan juli 2007. Ketua Mahkamah Konstitusi (MK) ketika itu memeriksaa dua perkara No. 2/PUU-V/2007 yang diajukan oleh empat orang, yaitu Edith Sianturi dan Rani Andriani, keduanya sedang menjalani hukuman di lembaga pemasyarakatan khusus wanita, Tangerang, serta Myuran sukmaran dan Andrew Chan, keduanya warganegara Australia yang sedang menjalani hukuman dilembaga pemasyarakatan krobokan, Kuta Bali, yang diwakili Kuasa hukumnya, Todung Mulya Lubis. Para pemohon merupakan terpidana mati yang telah menjalani proses persidangan mulai dari tingkat pengadilan Negeri hingga Mahkamah Agung dalam perkara tindak pidana yang diatur dalam UU Nakotika (Todung Mulya Lubis, 2009)., MK menolak peromohonan Uji materi UU Narkotika tersebut dengan alasan dalam UU Narkotika tidak bertentangan dengan hak hidup yang dijamin UUD 1945 lantaran jaminan hak asasi manusia dalam UUD 1945 tidak menganut asas kemutlakan. Menurut MK, hak asasi dalam konstitusi mesti dipakai dengan menghargai dan menghormati hak asasi orang lain demi berlangsungnya ketertiban umum dan keadilan sosial. Dengan demikian, MK, hak asasi manusia harus dibatasi dengan instrumen Undang-Undang, yakni Hak untuk hidup itu tidak boleh dikurangi, kecuali diputuskan oleh pengadilan.

Alasan lain pertimbangan putusan MK salah satunya karena Indonesia telah terikat dengan konvensi internasional narkotika dan psikotropika yang telah diratifikasi menjadi hukum nasional dalam UU Narkotika. Sehingga, menurut putusan MK, Indonesia justru berkewajiban menjaga dari ancaman jaringan peredaran gelap narkotika skala internasional, yang salah satunya dengan menerapkan hukuman yang efektif dan maksimal.. Dengan menerapkan hukuman berat melalui pidana mati untuk kejahatan serius seperti narkotika, MK berpendapat, Indonesia tidak melanggar perjanjian 
internasional apa pun, termasuk Konvensi Internasional Hak Sipil dan Politik (ICCPR) yang menganjurkan penghapusan hukuman mati. Bahkan MK menegaskan, Pasal 6 ayat 2 ICCPR itu sendiri membolehkan masih diberlakukannya hukuman mati kepada negara peserta, khusus untuk kejahatan yang paling serius. Dalam pandangan MK, keputusan pembikin undang-undang untuk menerapkan hukuman mati telah sejalan dengan Konvensi PBB 1960 tentang Narkotika dan Konvensi PBB 1988 tentang Pemberantasan Peredaran Gelap Narkotika dan Psikotropika, Pasal 3 Universal Declaration of Human Rights, dan UU HAM sebab ancaman hukuman mati dalam UU Narkotika telah dirumuskan dengan hati-hati dan cermat, tidak diancamkan pada semua tindak pidana Narkotika yang dimuat dalam UU tersebut. Lebih lanjut, melihat pada UU HAM, MK memandang bahwa UU itu juga mengakui adanya pembatasan hak asasi seseorang dengan memberi pengakuan hak orang lain demi ketertiban umum. Dalam hal ini, MK menganggap hukuman mati merupakan bentuk pengayoman negara terhadap warga negara terutama hak-hak korban.

Sejumlah ahli baik dari kalangan akademisi maupun praktisi dan aparat penegak hukum dihadirkan dalam sidang pengujian UU Narkotika tersebut. Berbagai pendapat dilontarkan yang semuanya hampir sama-sama kuat dan logis. Terdapat dua arus pemikiran, yaitu; pertama, mereka yang kontra pidana mati menganggap bahwa dalam hal tindak pidana narkotika pidana penjara atau pidana mati lebih banyak tidak efesien daripada tujuan yang ingin dicapai, yakni timbulnya efek jera. Hal ini terlihat bahwa walaupun sudah banyak yang dijatuhkan pidana mati, tetap saja jumlah kasus narkoba tidak berkurang, bahkan bertambah. Sementara, yang pro pidana mati, menganggap masih perlu dan harus dipertahankan. Ancaman hukuman mati masih diperlukan untuk memberikan efek jera. Kepada para pelaku kejahatan dan mencegah pelanggaran yang lebih parah, terutama dalam hal kasus narkotika. Satu-satunya cara untuk memutus mata rantai narkotika adalah dengan menjatuhkan pidana mati kepada pelaku narkoba. Hal ini untuk melindungi kepentingan negara dan masyarakat dari bahaya narkotika. Setelah mendengar berbagai pendapat tersebut, MK perlu juga mendengar tim perumus RUU KUHP yang diwakili oleh Mardjono Reksodiputro. Menurutnya RUU masih masih mengadopsi pidana mati, hukuman mati masih diperlukan tapi bukan pada pidana pokoknya. "Ia harus menjadi pidana khusus yang diterapkan secara hati-hati, selektif dan khusus pada kasus-kasus berbahaya dan harus ditetapkan bulat oleh majelis hakim" (Todung Mulya Lubis : 2009) 


\section{Penerapan Peraturan Perudang-Undangan Terkait Pidana Mati Di Indonesia}

Hukum yang mengatur tentang perbuatan-perbuatan apa yang diancam pidana dan dimana aturan pidana itu menjelma disebut hukum pidana. Oleh karena itu, hukum pidana disebut sebagai Hukum Sanksi Istimewa. Penjatuhan pidana sebagai penderitaan kepada pelanggar hanya merupakan obat terakhir (Ultimum Remedium) yang hanya dijalankan jika usaha-usaha lain seperti pencegahan sudah tidak berjalan. Salah satu bentuk pidana yang paling berat adalah Pidana Mati. (Andi Hamzah dan A. Sumangelipu, 1984 : 11 ).

\section{PENUTUP}

Berdasarkan urain tersebut diatas maka penulis dapat menarik kesimpulan sebagai berikut :

1. Secara sosiologis, hukuman mempunyai arti sosial yang tertentu oleh karena kekuatan suatu sanksi tergantung pada persepsi manusia mengenai sanksi/hukuman tersebut. Penjatuhan sanksi bertujuan untuk menghukum kejahatan atau menghukum perbuatan yang melanggar ketentuan sosial yang dianut. Dari aspek sosiologis masyarakat Indonesia penerapan pidana mati menimbulkan pro dan kontra, pihak yang setuju pidana mati (pro) umumnya didasarkan pada alasan konvensional yaitu pidana mati sangat dibutuhkan guna menghilangkan orang-orang yang dianggap membahayakan kepentingan umum atau negara dan dirasa tidak dapat diperbaiki lagi, sedangkan mereka yang kontra terhadap pidana mati lazimnya menjadikan alasan pidana mati bertentangan dengan hak asasi manusia dan merupakan bentuk pidana yang tidak dapat lagi diperbaiki apabila setelah eksekusi dilakukan, ditemukan kesalahan atas vonis yang dijatuhkan hakim.

2. Terkait dengan penegakan HAM penerapan pidana mati juga menimbulkan Pro dan Kontra, beberapa pihak yang kontra mengemukakan alasan bahwa penerapan pidana mati merupakan suatu bentuk pelanggaran HAM dan hal ini mereka dasarkan kepada adanya International Covenant on Civil and Political Right (ICCPR) dimana di Indonesia sendiri pengaturan menganai Hak untuk hidup jelas tercantum pada Pasal 9 Undang-Undang Nomor 39 Tahun 1999 tentang Hak Asasi Manusia dikatakan dalam UU ini bahwa setiap orang berhak atas kehidupan, mempertahankan kehidupan, dan meningkatkan taraf kehidupannya lebih lanjut menurut meraka yang kontra , penerapan pidana mati merupakan suatu bentuk pelanggaran konstitusi (inkonstitusional) mereka berdasar kepada Bunyi pasal 28A Undang-Undang Dasar 1945 (“UUD 1945”)yang berbunyi: "Setiap orang berhak untuk hidup serta berhak 
mempertahankan hidup dan kehidupannya. "Sedangkan pihak yang pro beranggapan bahwa Ancaman hukuman mati masih diperlukan untuk memberikan efek jera ,dalam hal kasus narkotika satu-satunya cara untuk memutus mata rantai narkotika adalah dengan menjatuhkan pidana mati kepada pelakunya. Terkait dengan pelannggaran HAM pihak yang mendukung pidana mati ini beranggapan bahwa hak untuk hidup memang benar dijamin dalam konstitusi Indonesia, namun hak tersebut dapat dibatasi dengan instrumen undang-undang. Konstitusionalitas hukuman mati telah diatur sejumlah undang-undang, salah satunya UU Narkotika, dan juga telah diperkuat oleh adanya putusan Mahkamah Konstitusi.

\section{DAFTAR PUSTAKA}

Andi Hamzah dan Sumangelipu, (1984), Pidana Mati Di Indonesia Di Masa lalu, Kini Dan DiMasa Depan, Jakarta: Ghalia Indonesia.

Djoko Prakoso dan Nurwachid, (1983), Studi Tentang Pendapat-Pendapat Mengenai EfektivitasPidana Mati Di Indonesia Dewasa Ini, Jakarta: Ghalia Indonesia.

J.E. Sahetapy, (1978), Suatu Studi Khusus Mengenai Ancaman Pidana Mati Terhadap Pembunuhan Berencana, Jakarta:Rajawali Pers

Nata Sukam Bangun, (2014), Jurnal Ilmiah: Eksistensi Pidana Mati Dalam Sistem Hukum Indonesia, Yogyakarta : Fakultas Hukum Universitas Atmajaya

Satjipto Rahardjo, Sosiologi Hukuman Mati, Ditulis untuk "Jurnal Legalitas Indonesia", www.legalitas.org

Soekanto, Soerjono, (1985), Efektivifikasi Hukum Dan Peranan Sanksi, Bandung: Remadja Karya.

Todung Mulya Lubis, (2007), Catatan Hukum Todung Mulya Lubis Mengapa Saya Mencintai Negeri Ini ?, Jakarta : PT. Kompas Media Nusantara , (2009), Kontroversi Hukuman Mati Perbedaan Pendapat Hakim Konstitusi, Jakarta : PT. Kompas Media Nusantara

Waluyadi, (2009), Kejahatan,Pengadilan dan Hukum Pidana, Bandung : Mandar Maju 